\title{
Ethics of Vaccination in Childhood
}

Meta Rus, Urh Grošelj

\section{Izvleček}

V državah z dobro vzpostavljenimi cepilnimi programi je cepljenje "žrtev lastnega uspeha", saj je nizka pojavnost bolezni, ki jih preprečujemo s cepljenjem, zmanjšala izkušnjo njihovega bremena in s tem očitnost koristi cepljenja. Povečevanje števila staršev, ki zavračajo cepljenje svojih otrok, je že ogrozilo t. i. skupnostno imunost oz. jo zmanjšalo celo do mere, da so se ponovno začeli pojavljati izbruhi prej obvladanih nalezljivih bolezni. V prispevku predstavljamo sistematični pristop k etičnim vprašanjem glede cepljenja otrok skozi štiri principe biomedicinske etike ( $t$ j. spoštovanje posameznikove avtonomije, neškodovanje, dobrodelnost in pravičnost), ki je razumljiv model za razmislek o tovrstnih vprašanjih. Pediatrom na primarni ravni, ki se najpogosteje srečujejo z dilemami glede obravnave otrok, katerih starši zavračajo cepljenje, je lahko sistematičnost opisanega pristopa v pomoč pri etičnem razmisleku, odločanju in iskanju lastne vloge $v$ tovrstnih situacijah. Utemeljujemo iskanje "etičnega ravnovesja", kar pomeni, da stopnja spoštovanja avtonomije staršev ni stalna, ampak odvisna od ravni vzpostavljene skupnostne imunosti. če moralna dolžnost posameznikov, da prispevajo $\mathrm{k}$ imunosti populacije, ni izpolnjena, je upravičeno s strani države predpisano obvezno cepljenje. Država je namreč odgovorna za varovanje skupnostne imunosti, ki jo moramo razumeti kot javno dobro in zato potrebuje posebno državno zaščito.

Ključne besede: cepljenje, etika, otroci, načela biomedicinske etike, skupnostna imunost, avtonomija, skupno dobro, pravičnost.

\section{Abstract}

In countries with well-established immunisation programmes, vaccination is the 'victim of its own success', because the low incidence of diseases prevented by vaccines has diminished the experience of their historical burdens and hence the obvious benefit of vaccination. The increasing number of parents who reject vaccination of their children already threatens or even effectively disables herd immunity level of the population and results in outbreaks of previously already controlled infectious diseases. We aimed to design a framework for ethical analysis of vaccination in childhood based on the four principles of biomedical ethics (respect for autonomy, nonmaleficence, beneficence and justice) to provide a comprehensive and applicable model for addressing the ethical aspects of vaccination at both the individual and societal levels.

The principle-based framework can be especially useful to paediatricians in primary care when looking for the best approach to the treatment of children of vaccine-hesitant parents. We suggest finding an 'ethical equilibrium', which means that the degree of respect for parents' autonomy is not constant, but variable; it depends on the level of established herd immunity and it is specific for every society. When the moral obligation of individuals to contribute to herd immunity is not fulfilled, mandatory vaccination policies are ethically justified, because states bear the responsibility to protect herd immunity as a common good.

Key words: vaccination, ethics, children, principles of biomedical ethics, herd immunity, autonomy, common good, justice 


\section{Uvod}

Čeprav je cepljenje eden najpomembnejših javnozdravstvenih dosežkov v zgodovini medicine, ki je rešilo milijone življenj in ključno podaljšalo pričakovano življenjsko dobo, med ljudmi ni deležno splošne sprejetosti. Lahko bi rekli, da je v državah z dobro vzpostavIjenimi cepilnimi programi celo "žrtev lastnega uspeha", saj je nizka pojavnost bolezni, ki jih danes preprečujemo s cepljenjem, zmanjšala izkušnjo njihovega bremena in zato marsikdo ni več prepričan $v$ njeno koristnost (1). Med ljudmi srečamo spekter različnih mnenj; tako nekateri nasprotujejo cepljenju zaradi določenih principov in prepričanj, drugi nasprotujejo le obveznemu cepljenju in vmešavanju države, spet tretji so zaskrbljeni glede varnosti cepiv in bi cepljenje svojih otrok raje odložili, nekateri pa $v$ učinkovitost cepiv preprosto ne verjamejo. $V$ zadnjem času se je $v$ tuji literaturi uveljavil izraz "vaccine hesitancy", slovensko zadržanost oz. neodločenost glede cepljenja, ki zajema celoten kontinuum mnenj med obema skrajnostima, tj. zagretimi zagovorniki cepljenja in izrazitimi nasprotniki. Število ljudi, ki so zadržani do cepljenja, je veliko večje od števila izrazitih nasprotnikov cepljenja. Po podatkih lestvice Svetovne zdravstvene organizacije (SZO) 'WHO SAGE Vaccine Hesitancy Scale' ima po nekaterih podatkih do $90 \%$ ljudi pomisleke vsaj glede enega vidika cepljenja, medtem ko cepljenje $v$ celoti zavrača le približno $5 \%$ staršev (2). Zadržanost do cepljenja je v bolj razvitih državah glavni razlog nižje stopnje precepljenosti in ponovnega pojavljanja nekaterih nalezljivih bolezni, kot so ošpice (3).

Preventivno cepljenje je $z$ etičnega vidika kompleksno področje, saj vključuje tako individualno kot javnozdravstveno perspektivo. Na ravni družbe so glavne etične dileme povezane s postopki razvoja cepiv in njihovo pravično porazdelitvijo, obveznim cepljenjem potnikov in delavcev ter etično upravičenostjo obveznega cep- ljenja otrok za zagotovitev skupnostne imunosti $(4,5)$. Na ravni posameznika se pojavljajo konflikti med spoštovanjem avtonomije staršev, dobrobitjo otroka in pravičnim doprinosom $\mathrm{k}$ skupnostni imunosti $(6,7)$. Čeprav ima tudi Slovenija, podobno kot druge države, svojo politiko cepljenja in svoje smernice, je vsaka situacija obravnave otroka staršev, ki so zadržani do cepljenja, edinstvena in zahteva individualno obravnavo.

$\checkmark$ prispevku opredeljujemo pristop skozi štiri načela biomedicinske etike (spoštovanje posameznikove avtonomije, neškodovanje, dobrodelnost, pravičnost), ki sta jih leta 1979 prvič opredelila Childress in Beauchamp ter so kmalu postala temelj medicinske etike (8). Sistematičnost tovrstnega okvira ponuja širši pogled na problematiko cepljenja in je predvsem pediatrom na primarni ravni lahko $v$ pomoč pri oblikovanju stališč in odločanju glede obravnave otrok, katerih starši zavračajo cepljenje.

\section{Spoštovanje avtonomije}

Načelo spoštovanja posameznikove avtonomije je spoštovanje njegove pravice, da sam odloča o sebi glede na lastna prepričanja, pri čemer lahko - z medicinskega vidika sicer koristen - poseg tudi zavrne (8). Možnost odločanja posamezniku hkrati prinese tudi odgovornost za posledice sprejete odločitve (8). To načelo je $v$ zadnjih 50 letih eno temeljnih načel $v$ zahodni medicini (9), ki pa nikakor ni absolutno in ne sme predstavljati sodobnega individualizma, kot trdijo nekateri kritiki, ampak mora biti uravnoteženo $z$ ostalimi etičnimi načeli in odgovornostjo do družbe (10).

\section{Pogoji za veljavno zavrnitev cepljenja}

$\checkmark$ praksi se avtonomija pacientov (oz. njihovih zastopnikov) uresničuje preko privolitve oz. zavrnitve po pojasnitvi. Za to morajo biti izpolnjena vsaj štiri merila, ki jih predstavljamo v Tabeli 1. Izpolnitev naštetih meril pogosto pomeni razrešitev navidezne dileme, ki se pojavi ob zavračanju cepljenja.

\section{Razpetost med avtonomijo staršev in dobrobitjo otroka}

Ker je večina cepljenj na programu v zgodnjem otroštvu, ko otroci še niso zmožni tolikšnega razumevanja, da bi lahko govorili o njihovi avtonomiji (tj. da bi lahko sprejemali odločitve $v$ lastnem imenu in lastnem interesu), se namesto njih odločajo njihovi starši (oz. skrbniki). Ker se ti lahko odločijo v njihovo škodo (npr. zaradi pomanjkljivega znanja kljub izpolnjeni pojasnilni dolžnosti, zaradi različnih zmotnih prepričanj, zaradi malomarnosti), se pojavlja vprašanje, v kolikšni meri so pristojni za odločanje glede cepljenja svojih otrok. $V$ pediatriji odločanje poteka v okviru triade otrok-starš-pediater, pri čemer otrokovo zdravstveno korist zastopa pediater (16). Pediater je "zagovornik" otroka (kot pacienta), starši pa so "odločevalci". Pediater mora zato zagotoviti, da je odločitev v otrokovo dobro, a je prag za bolj restriktivne ukrepe razmeroma visok. Na prvem mestu je pogovor s starši, sledi obravnava v okviru konzilija specialistov in nazadnje morda celo naslovitev pristojne etične komisije. Po doktrini parens patriae je namreč tudi država tista, katere interes in dolžnost sta, da varuje zdravje otrok (17). Vendar pa je zakonski prag za sodni odvzem starševskih pravic razmeroma visok; $v 172$. členu Družinskega zakonika je namreč opredeljeno, da lahko sodišče odloči o zdravniškem pregledu ali zdravljenju otroka brez soglasja staršev le takrat, ko je ogroženo otrokovo življenje ali huje ogroženo njegovo zdravje (kar se $v$ praksi nanaša na večje zlorabe ali zanemarjanje otroka) (18). Vprašanje necepljenja praviloma praga za poseg države v starševstvo nikoli ne doseže. 
- Pomembna je vloga staršev (glej tudi odstavek 2.2), saj je večina cepljenj na razporedu v zgodnjem otroštvu, ko otrok še ni zmožen samostojnega odločanja.

- Pomen zadostne informiranosti staršev o cepljenju, pričakovanih koristih in možnih tveganjih.

- Nezadostna informiranost ali napačne informacije so pogost razlog zavračanja cepljenja (11).

- Zaupanje družbe v znanstvena dognanja glede cepljenja, v zdravstveni sistem in politiko cepljenja je ključno, a ne samoumevno in zahteva transparentno navajanje informacij o cepivih in neželenih učinkih, poenoteno stališče znanosti, medicinskih strok in njihovih predstavnikov ter prevzem odgovornosti s strani države za morebitne neželene učinke $(7,12)$.

- Izreden pomen zaupljivega odnosa med starši in otrokovim pediatrom (namenjanje pozornosti skrbem staršev glede cepljenja) (12).

- Prednosti sistematičnega pristopa podajanja informacij zaradi časovne omejenosti ambulantne obravnave (npr. preko sredstev družbenega obveščanja in organiziranih izobraževanj).

razumevanje

- Nujen pogoj, saj odločitev prinese tudi odgovornost za posledice sprejetih odločitev.

- Dolžnost javnozdravstvenih ustanov in pristojnih zdravstvenih delavcev je, da staršem podajo informacije na način, da jih ti razumejo (13).

- Pravilno poznavanje koristi in tveganj ter razumevanje koncepta cepljenja (tudi) kot altruističnega dejanja nekaterim staršem pomaga, da sprejmejo breme cepljenja (14).

prostovoljnost

- Svoboda odločanja kot ključni del privolitve oz. zavrnitve po pojasnitvi.

- Vpliv različnih dejavnikov na mnenje staršev glede cepljenja (npr. lastne izkušnje, družbeni miti, prepričanja prijateljev ali sorodnikov, zdravnikovo mnenje) (15).

- Številni dejavniki ne ogrožajo avtonomije, ampak so celo ključni del sprejemanja odločitev (angl. non-controlling influence) (8).

- Potreba po prepoznavanju in odpravi dejavnikov, ki omejujejo svobodo staršev in so lahko med razlogi za zadržanost glede cepljenja (angl. controlling influence), npr. teorije zarote, pritiski s strani bližnjih oseb ipd. (15).

TABELA 1. POGOJI ZA VELJAVNOST PRIVOLITVE OZ. ZAVRNITVE PO POJASNITVI S POUDARKOM NA CEPLJENJU.
TABLE 1. CONDITIONS FOR THE VALIDITY OF INFORMED CONSENT OR REFUSAL APPLIED TO VACCINATION.
Ima pa država tudi druge mehanizme (npr. kazni za necepitelje, cepljenje kot pogoj za vpis v vrtec ali šolo), s katerimi lahko pomembno pomaga pediatru kot zagovorniku otroka v primeru cepljenja.

Stopnja avtonomije staršev je tako odvisna od vrste načrtovanega posega (oz. vrste cepiva). Večje kot je razmerje med koristjo in bremenom posega, manjša je avtonomija staršev in obratno (Slika 1). Pri cepljenju je tveganje zelo majhno, koristi pa zaradi učinka skupnostne imunosti) presegajo koristi za posameznega otroka, kar kaže na manjšo vlogo staršev pri odločanju glede cepljenja. V naši družbi je v splošnem staršem dopuščena precejšnja avtonomija tako pri vzgoji otrok kot pri različnih odločitvah glede otrok, zato je neizbežno, da jo upoštevamo tudi pri cepljenju. Seveda z zavedanjem, da gre za dobrobit otrok (in ne staršev samih), zato mora biti obseg spoštovanja avtonomije staršev omejen.

\section{Ugovor vesti staršev in medicinskega osebja}

Tudi če je zadoščeno vsem pogojem za avtonomno sprejemanje odločitev, ki jih predstavljamo v Tabeli 1, nekateri starši cepljenje npr. iz verskih ali moralnih vzrokov še vedno zavračajo (8). Pojavljajo se vprašanja, ali sta na mestu možnost ugovora vesti staršev in opustitev cepljenja iz nemedicinskih vzrokov ter kakšnim omejitvam naj bi bila ta možnost podvržena (19). Clarke s sod. pravi, da naj bi starši imeli to možnost zgolj v primeru, ko na ta način ni ogrožena skupnostna imunost prebivalstva (20). V letu 2020 sta v Evropi nemedicinske vzroke odstopa od cepljenja dopuščali zgolj dve državi (21).

Poleg staršev imajo svojo avtonomijo tudi zdravstveni delavci in jo uveljavljajo preko pravice do ugovora vesti. Nekateri zdravniki po svetu zavračajo zdravljenje necepljenih otrok iz razlogov, kot sta ogrožanje otrok, ki se iz utemeljenih razlogov ne morejo cepiti, in slabša oskrba pacientov, ki jim ne moremo posvetiti dovolj časa (22). Ker je lahko z ugovorom vesti pediatrov za primer cepljenja okrnjen dostop otrok do zdravstvene oskrbe, je možnost ugovora vesti v tem primeru vprašljiva (23) in je skrajen ukrep, ko pediater zazna, da svojim pacientom ne more več nuditi kakovostne in varne zdravstvene oskrbe. Odgovornost oz. vloga države je, da s pravno ureditvijo pediatrom nudi pogoje, da do tovrstnih dilem $v$ prihodnje sploh ne pride. $Z$ ustreznimi in učinkovitimi pravnimi podlagami je dolžna sistematično pristopati k staršem, ki zavračajo cepljenje, ter $z$ različnimi strategijami skrbeti za zadostno precepljenost otrok (več v poglavju Pravičnost).

\section{Neškodovanje}

Načelo neškodovanja pomeni, da se pacientu ne povzročamo škode. Je eno poglavitnih načel $v$ medicini (8). Če zdravnik ugotovi, da je poseg oz. zdravljenje potencialno škodljivo, je pomembno, da presodimo o ugodnosti razmerja med škodo in koristjo za pacienta (8). 


\section{Neželeni učinki cepiv}

Čeprav je cepljenje v splošnem zelo varen poseg, ni povsem brez tveganja. V okviru načela neškodovanja je potreben razmislek o neželenih učinkih. Ker cepiva običajno dajemo zdravim otrokom, ki imajo od njih le omejeno neposredno korist, vsakršni neželeni učinki negativno vplivajo na razmerje med koristjo in škodo za otroka (15). Večina neželenih učinkov je blagih; resnejše reakcije, kot so anafilaksija, vročinski krči in imunska trombocitopenična purpura, so redke in se jih ugotavljamo šele $v$ daljšem obdobju po odobritvi cepiva (15). Zaradi napačnih povezav med določenimi cepivi in bolezenskimi stanji $v$ preteklosti so se razvili številni miti, ki dodatno spodbujajo nezaupanje $v$ cepiva (npr. povezanost med cepivom OMR in avtizmom, ki so jo s trdnimi dokazi ovrgli) (24). Rešitev je zagotavljanje zanesljivih informacij staršem in transparentnost podatkov glede vsakršnih neželenih učinkov (15).

\section{Opustitev cepljenja}

Čeprav so cepiva primerna za večino otrok, je dolžnost zdravnika, da prepozna posameznike, pri katerih morebitne koristi cepljenja ne odtehtajo tveganja in je zato zanje upravičena opustitev cepljenja (15). Opustitev je lahko začasna ali trajna, pri nekaterih posameznikih pa je ob cepljenju potrebna zgolj večja pazljivost. $V$ izogib zmotam glede opustitve cepljenja ter za zagotovitev varnosti pacientov konsistentnosti njihove obravnave, morajo biti smernice jasne in dostopne (25).

\section{Klinične raziskave cepiv}

V okviru načela neškodovanja je na mestu tudi razmislek o postopkih razvoja cepiv, saj so tveganja za udeležence $v$ raziskavah pogosto nejasna. Ker imajo otroci manjše zmožnosti razumevanja in so lahko podvrženi prisili, jih obravnavamo kot ranljivo populacijo, kar zahteva posebno pozornost in določene omejitve v izvajanju raziskav (26). Po drugi strani imajo otroci pravico do novih načinov zdravljenja in preprečevanja bolezni s cepljenjem, zato so klinične raziskave na otrocih neizogibne in nujne (26).

\section{Dobrodelnost}

Načelo dobrodelnosti opredeljuje primarno zdravnikovo poslanstvo - prispevati k dobrobiti pacientov (8). Je nadgradnja načela neškodovanja, saj od zdravnika zahteva aktivna dejanja v smeri čim večje koristi pacienta (8). To načelo je temelj zaupanja družbe tako $v$ zdravstveni sistem kot tudi $v$ medicinsko osebje, kar je ključno tudi za učinkovitost programov cepljenja (27). Načelo dobrodelnosti se ne nanaša zgolj na posameznika, pač pa tudi na družbo kot celoto (npr. v kontekstu cepljenja ali kliničnih raziskav) (8).

\section{Koristi cepljenja za posameznika in za družbo}

Cepljenje je prispevalo k očitnemu zmanjšanju razširjenosti določenih nalezljivih bolezni oz. celo $\mathrm{k}$ njihovemu izkoreninjenju (28). Ko gre za cepljenje proti nenalezljivim infekcijskim boleznim (npr. tetanus, KME) ali v primeru, ko kolektivna imunost še ni vzpostavljena (npr. covid-19), je korist cepljenja za posameznika očitna (6). Ko je določena raven imunosti populacije že dosežena (npr. polio), pa ima cepljenje za posameznika omejeno korist, saj je verjetnost okužbe $z$ odpravljenimi povzročitelji zelo zmanjšana (6). Pri tehtanju glede tveganj in koristi moramo upoštevati tudi korist za širšo populacijo preko skupnostne imunosti, ki se vzpostavi le s cepljenjem posameznikov.

\section{Pravičnost}

Načelo pravičnosti terja sorazmerno razporeditev koristi, tveganj in bremen oz. čim bolj podobno obravnavo posameznikov, ki se nahajajo v enakih ali primerljivih okoliščinah (8). $V$ povezavi s cepljenjem to načelo zahteva enakovredno dostopnost do cepiv, kar je $v$ Sloveniji ( $v$ nasprotju z nekaterimi državami v razvoju) aktualno vprašanje predvsem v povezavi s cepivom proti covid-19. Drugo področje načela pravičnosti v etiki cepljenja pa je pravično prispevanje k skupnostni imunosti, kar opisujemo v nadaljevanju.

\section{Skupnostna imunost kot javno dobro}

Skupnostna (oz. kolektivna ali čredna) imunost je javno dobro. To pomeni, da je vsakdo deležen njene koristi, pri čemer novi posamezniki ne zmanjšajo njene razpoložljivosti (podobno kot pri pitni vodi ali čistem zraku) (6). Skupnostna imunost je po eni strani oblika solidarnosti z ranljivimi osebami v populaciji, saj pred okužbami varuje tudi tiste, ki se iz različnih vzrokov ne morejo cepiti (29), po drugi strani pa dopušča obstoj neupravičenega okoriščanja (angl. free-rider), ko posamezniki uživajo koristi skupnostne imunosti, ne da bi k njej prispevali in prevzeli določeno breme, ki ga cepljenje vseeno predstavlja (30). Ko je skupnostna imunost populacije vzpostavljena in je nevarnost nalezljivih bolezni manjša, je izziv ohranjanje zadostne ravni imunosti v populaciji (30).

\section{Odgovornost države in etična upravičenost obveznega zdravstvenega posega}

Skrb za javno zdravje je v pristojnosti države (31). Tako kot je država odgovorna za varnost udeležencev v pro- 
metu, je pristojna tudi za obvladovanje nalezljivih infekcijskih bolezni in uravnavanje kolektivne imunosti $(12,29$, 30). Ponovni izbruhi sicer odpravljenih ali obvladanih bolezni kažejo, da prostovoljno cepljenje in njegova promocija nista vedno zadostna ter da je v določenih okoliščinah upravičeno tudi obvezno cepljenje $(6,30)$. Gostin navaja naslednje pogoje za uvedbo obveznega medicinskega posega: neučinkovitost ukrepa na prostovoljni ravni; odsotnost alternative $\mathrm{z}$ manj prisile; nedvoumna znanstveno-strokovna podlaga in podvrženost članov družbe tveganju, ki se ga ti ne zavedajo (32). Avtorji trdijo, da imajo posamezniki moralno dolžnost, da prispevajo k skupnostni imunosti; če ta ni izpolnjena na prostovoljni ravni in je ogrožena imunost populacije, je upravičeno obvezno cepljenje (6, 33-35). Tega moramo uvajati postopno in najprej izvesti najmanj omejujoče še učinkovite ukrepe $(6,33)$. Ukrepi za doseganje zadostne imunosti so lahko naravnani pozitivno in naredijo cepljenje bolj privlačno (npr. izobraževanje ali finančni dodatek za cepljene otroke) ali pa naravnani negativno (npr. denarne kazni ali prepoved vpisa v vrtec ali šolo) (36). Čeprav nekateri dvomijo v dolgoročno učinkovitost obveznega cepljenja (zaradi nevarnosti povratnega učinka (angl. rebound problem) in okrepljenega nezaupanja v cepljenje) ter zagovarjajo politike cepljenja, ki temeljijo na solidarnosti in odgovornosti državljanov $(27,37)$, so v nedavnih raziskavah pokazali, da je obvezno cepljenje učinkovito tako glede večje precepljenosti kot tudi večjega zaupanja prebivalcev v cepiva $(21,38)$. Ne glede na politiko cepljenja pa je ključno, da spodbujamo odgovornost staršev preko izobraževanja o konceptu skupnostne imunosti in koristih cepljenja, ki presegajo koristi zgolj za posameznega otroka $(7,27)$.

\section{Razpravljanje}

Pristop do etike cepljenja otrok preko štirih principov biomedicinske etike nam s širino in sistematičnostjo



SLIKA 1. ODNOS MED AVTONOMIJO STARŠEV TER RAZMERJEM MED KORISTMI IN TVEGANJI (ALI DRUŽBENO PRAVIČNOSTJO) ZA CEPLJENJE. KRIVULJA SE OB ZADOSTNI RAVNI SKUPNOSTNE IMUNOSTI PREMAKNE NAVZGOR, KAR DAJE VEČJO AVTONOMIJO STARŠEM IN NUDI POTENCIALNO MOŽNOST OPUSTITVE CEPLJENJA IZ NEMEDICINSKIH VZROKOV.

FIGURE 1. RELATIONSHIP BETWEEN PARENTAL AUTONOMY AND THE BENEFIT-TO-RISK RATIO (OR SOCIETAL JUSTICE) FOR VACCINATION. IF THERE IS SUFFICIENT HERD IMMUNITY, THE CURVE COULD BE SHIFTED UPWARDS, ALLOWING A HIGHER DEGREE OF AUTONOMY FOR PARENTS, AND POSSIBLY EVEN ALLOWING VACCINATION REFUSAL FOR SELECTED NON-MEDICAL REASONS. 


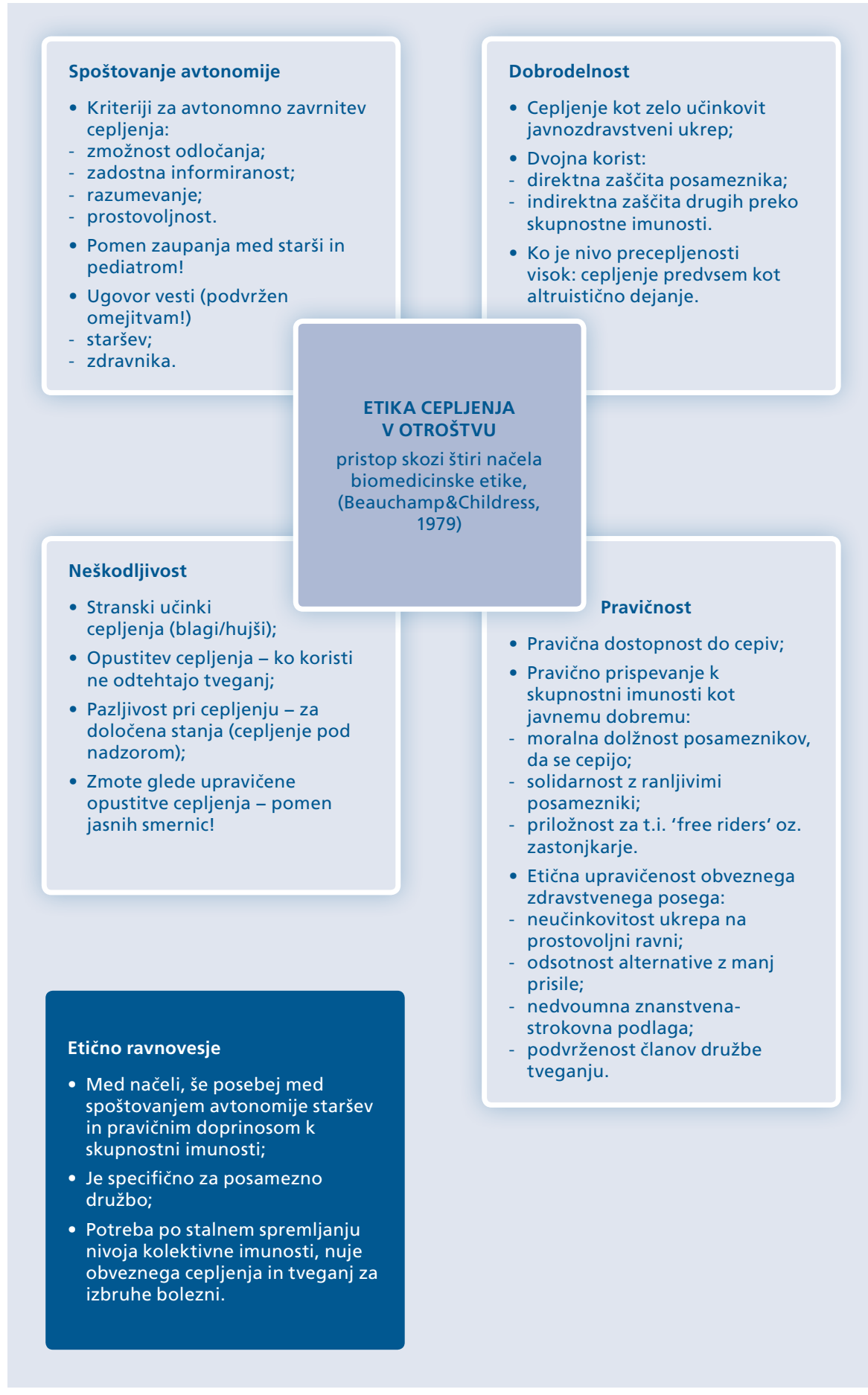

SLIKA 2. ETIKA CEPLJENJA OTROK PREKO ŠTIRIH NAČEL BIOMEDICINSKE ETIKE.

FIGURE 2. SUMMARY OF THE ETHICAL ASPECTS OF VACCINATION OF CHILDREN FROM THE PERSPEC TIVE OF THE FOUR PRINCIPLES OF BIOMEDICAL ETHICS. lahko pomembno pomaga pri razmisleku in odločanju. Kot trdita Beauchamp in Childress, avtorja štirih principov biomedicinske etike, je glavni izziv iskanje ravnovesja med posameznimi načeli (8). $V$ etiki cepljenja sta $v$ ospredju naslednja konflikta: 1) konflikt med spoštovanjem avtonomije staršev in dobrobitjo otroka ter 2) konflikt med spoštovanjem avtonomije staršev in pravičnim doprinosom k skupnostni imunosti (35). Ker je vsaka dilema pri soočenju s starši, ki so zadržani do cepljenja svojih otrok, specifična in zahteva individualen pristop, predlagamo sistematičen razmislek preko štirih principov, ki ga nakazujemo v nadaljevanju.

Kot prvo moramo $v$ okviru načel dobrodelnosti in neškodljivosti pretehtati tveganja in koristi cepljenja posameznega otroka ob hkratnem upoštevanju koristi za splošno populacijo. $V$ splošnem so koristi tako za posameznika kot za družbo veliko večje od tveganj, saj so hujši neželeni učinki izjemno redki. Če pa je tveganje zapletov povečano, je pri cepljenju potrebna bodisi pazljivost ali pa je upravičena opustitev cepljenja (začasna ali trajna). Pri odločanju so nam lahko $v$ pomoč povzetki značilnosti posameznih cepiv in najnovejše smernice glede opustitve cepljenja $(25,39)$. Če se pojavijo dvomi ali določeno zdravstveno stanje opravičuje opustitev cepljenja, svetujemo posvetovanje s strokovnjakom tega področja (25).

Načelo spoštovanja avtonomije zahteva pregled pogojev, ki so potrebni, da je odločitev (npr. zavrnitev cepljenja) sprejeta avtonomno. Starši morajo biti na njim razumljiv način informirani glede delovanja cepiv, vključno z morebitnimi tveganji. Imeti morajo možnost, da zastavijo vprašanja in izrazijo svoje skrbi. Prepoznati je potrebno tudi zmote in tiste vplive okolice, ki zmanjšujejo avtonomijo staršev (npr. proticepiteljska gibanja) $(1,8)$. Pomembno vlogo v obveščanju prebivalstva imajo različni javnozdravstveni pristopi, ki ciljajo na širšo populacijo 
in v družbi ustvarjajo splošno pozitivno naravnanost do cepljenja, kar se odraža v večjem sprejemanju cepiv in kritičnosti do lažnih informacij. Prav zapostavljenost informiranja prebivalstva s strani Nacionalnega inštituta za javno zdravje in slovenskih medijev je eden glavnih vzrokov za širjenje lažnih informacij in širitev proticepilskih gibanj. Trenutna situacija $z$ epidemijo covid-19 je vse opozorila na nujo izobraževanja družbe o delovanju cepiv ter hkrati povečala dojemljivost in zanimanje prebivalstva o tovrstnih temah. Sistematično obveščanje in izobraževanje imata prednost pred individualnim svetovanjem tudi iz ekonomskih in praktičnih vidikov, saj pediatrom $v$ ambulanti pogosto čas ne dopušča, da bi naslovili številne zadržke staršev.

Obveščanje o delovanju in koristih cepljenja mora biti naslovljeno ne le na splošno populacijo, temveč v prvi vrsti na zdravstvene delavce in sodelavce, saj so vir informacij za širšo družbo tako $v$ formalnih kot $v$ neformalnih okoljih. Hkrati je njihov zgled - ali se odločijo za cepljenje z neobveznimi cepivi - tudi ključen dejavnik pri odločanju laične populacije glede cepljenja (40). Nekonsistentnost mnenj med zdravstvenimi delavci je eden vzrokov zmede med ljudmi in širjenja lažnih informacij. Znano je, da so medicinske sestre in zdravstveniki bolj zadržani do cepljenja kot zdravniki, a so prav oni prvi stik zdravstvenega osebja s starši ter s svojimi stališči in zgledom vplivajo na njihovo mnenje (41, 42). Zato je ključno, da v prvi vrsti vse zaposlene $v$ zdravstvu poučimo o širših koristih cepljenja ter etičnih načelih in odgovornosti, ki jo kot predstavniki stroke nosijo s svojim zgledom. Če je problem necepljenja med zdravstveni delavci izrazit in lahko vodi v tveganja za paciente (npr. nizka precepljenost proti gripi $v$ okoljih, kjer poteka zdravstvena oskrba starostnikov), so etično sprejemljivi ali celo priporočljivi tudi ukrepi v smeri obveznega cepljenja za zaposlene, vsaj če ostali ukrepi niso zadostni (43).
Načelo pravičnosti terja pravičen doprinos k skupnostni imunosti, ki je javno dobro. Njeno uravnavanje je $v$ pristojnosti države. Če zadostne ravni imunosti ne moremo doseči na prostovoljni ravni, je upravičeno obvezno cepljenje. To načelo nasprotuje načelu spoštovanja avtonomije staršev, zato moramo najti ustrezno "etično ravnovesje". To pomeni, da stopnja avtonomije staršev ni nespremenljiva, ampak odvisna od ravni dosežene skupnostne imunosti - višja kot je, bolj lahko spoštujemo avtonomijo staršev. Na Sliki 1 to prikazujemo kot premik krivulje navzgor pri višji ravni precepljenosti. Načelo etičnega ravnovesja terja stalno spremljanje ravni skupnostne imunosti, nujnosti obveznega cepljenja in višine tveganja glede izbruhov bolezni.

Iskanje ravnovesja med spoštovanjem avtonomije staršev in ukrepi obveznega cepljenja je specifično za vsako državo. V Sloveniji se - npr. v nasprotju s skandinavskimi državami, kjer je precepljenost kljub neobveznemu cepljenju zadostna - vsaj v zadnjih letih gibamo na spodnjih mejah skupnostne imunosti (ali v nekaterih območjih že celo pod njimi), zato so možnosti spoštovanja avtonomije staršev bolj omejene. Podatki zadnjih let kažejo, da se precepljenost v Sloveniji pri večini bolezni zmanjšuje. Tako se je na primer precepljenost za ošpice, mumps in rdečke (OMR) s $94 \%$ zmanjšala na $91 \%$, za tetanus ( $v$ srednješolski populaciji) pa s $96 \%$ na $88 \%$ (44). Podatki glede deleža otrok, cepljenih z neobveznimi, a priporočenimi in zastonj cepivi (npr. proti pnevmokoku ali KME) kažejo, da bi bili v Sloveniji zgolj s prostovoljnim cepljenjem verjetno daleč pod zadostno ravnijo skupnostne imunosti za nekatere bolezni, kar bi se lahko kazalo z izbruhi (45). Četudi je v Sloveniji uzakonjeno obvezno cepljenje otrok (proti devetim boleznim), ki je od lani tudi pogoj za vpis v javni vrtec, to samo po sebi nikakor ni dovolj. Potrebni ukrepi so dosledno izvajanje in tudi nadzor nad upoštevanjem sprejetih ukrepov ter hkrati posvečanje pozornosti zadostnemu informiranju prebivalstva (46).

\section{Zaključek}

Skupnostna imunost morda ni najbolj očitna, a je zelo dragocena javna dobrina, ki koristi vsakomur. Ko je vzpostavljena zadostna raven imunosti, koristi cepljenja za posameznika niso več očitne, zato gre za predvsem altruistično dejanje. Če moralna dolžnost posameznikov, da prispevajo k skupnostni imunosti, ni izpolnjena, je upravičeno obvezno cepljenje, ki ga zagotavlja država, saj je odgovorna za varovanje skupnostne imunosti kot javne dobrine. Ker pa je cepljenje $v$ nasprotju z nekaterimi drugimi obveznimi ukrepi invaziven postopek (čeprav minimalno), je spoštovanje avtonomije (staršev) še bolj na mestu. Poiskati moramo optimalno ravnovesje med vzdrževanjem skupnostne imunosti in avtonomijo staršev, kar zahteva stalno tehtanje med upravičenostjo obveznega cepljenja in tveganji za izbruhe bolezni. Ne glede na politiko cepljenja pa je nujno spodbujati zaupanje javnosti v cepljenje ter vzpostaviti zaupljiv odnos med starši in otrokovim pediatrom.

\section{Opomba avtorjev}

Besedilo je skrajšana, nekoliko spremenjena in delno tudi dopolnjena različica besedila, ki je bilo objavljeno kot znanstveni prispevek (Rus, M.; Groselj, U. Ethics of Vaccination in Childhood A Framework Based on the Four Principles of Biomedical Ethics. Vaccines 2021, 9, 113. https://doi.org/10.3390/ vaccines9020113). Zaradi večje sporočilnosti sta dodani Tabela 1 in Slika 2. Avtorja sta na pobudo kolegov pripravila prispevek v želji, da bi bilo besedilo v slovenskem jeziku širše dosegljivo ter predvsem v pomoč kolegom pediatrom na primarni ravni in vsem drugim zainteresiranim. 


\section{Literatura}

1. Dubé E, Vivion M, MacDonald NE. Vaccine hesitancy, vaccine refusal and the anti-vaccine movement: Influence, impact and implications. Expert Rev Vaccines. 2015; 14 (1): 99-117.

2. Lane S, MacDonald NE, Marti M, et al. Vaccine hesitancy around the globe: Analysis of three years of who/unicef joint reporting form data2015-2017. Vaccine. 2018; 36 (26): 3861-7.

3. Phadke VK, Bednarczyk RA, Salmon DA, et al. Association between vaccine refusal and vaccine-preventable diseases in the united states: A review of measles and pertussis. Jama. 2016; 315 (11): 1149-58.

4. Hellmann F, Williams-Jones B, Garrafa V. Covid-19 and moral imperialism in multinational clinical research. Arch Med Res. 2020; 51 (6): $572-3$

5. Iserson KV. Sars-cov-2 (covid-19) vaccine development and production: An ethical way forward. Camb Q Healthc Ethics. 2020: 1-10.

6. Giubilini A, Douglas T, Savulescu J. The moral obligation to be vaccinated: Utilitarianism, contractualism, and collective easy rescue. Med Health Care Philos. 2018; 21 (4): 547-60.

7. Krantz I, Sachs L, Nilstun T. Ethics and vaccination. Scand J Public Health. 2004; 32 (3):

$172-8$

8. Beauchamp TL, Childress JF. The principles of biomedical ethics. 6th ed. New York: Oxford University Press; 2009.

9. Stammers T. The evolution of autonomy New Bioeth. 2015; 21 (2): 155-63.

10. Beauchamp T, Childress J. Principles of biomedical ethics: Marking its fortieth anniversary. Am J Bioeth. 2019; 19 (11): 9-12.

11. Dubé E, Gagnon D, MacDonald NE. Strategies intended to address vaccine hesitancy: Review of published reviews. Vaccine. 2015; 33 (34): 4191-203.

12. Nihlén Fahlquist J. Vaccine hesitancy and trust. Ethical aspects of risk communication. Scand J Public Health. 2018; 46 (2): 182-8.

13. Bedford HE, Elliman DAC. Fifteen-minute consultation: Vaccine-hesitant parents. Arch Dis Child Educ Pract Ed. 2020; 105 (4): 194-9.

14. Fernbach $A$. Parental rights and decision making regarding vaccinations: Ethical dilemmas for the primary care provider. J Am Acad Nurse Pract. 2011; 23 (7): 336-45.

15. Smith M. Vaccine safety: Medical contraindications, myths, and risk communication. Pediatr Rev. 2015; 36 (6): 227-38.

16. Tates K, Elbers E, Meeuwesen L, et al. Doctor-parent-child relationships: A, pas de trois'. Patient Educ Couns. 2002; 48 (1): 5-14.

17. Katz AL, Webb SA. Informed consent in decision-making in pediatric practice. Pediatrics. 2016; 138 (2).

18. Dosegljivo na: http://www.pisrs.si/Pis.web/ pregledPredpisa?id=ZAKO7556\#

19. Salmon DA, Siegel AW. Religious and philosophical exemptions from vaccination requirements and lessons learned from conscientious objectors from conscription. Public Health Rep. 2001; 116 (4): 289-95.

20. Clarke S, Giubilini A, Walker MJ. Conscientious objection to vaccination. Bioethics. 2017; 31 (3): 155-61.
21. Vaz OM, Ellingson MK, Weiss $P$, et al. Mandatory vaccination in europe. Pediatrics. 2020; 145 (2).

22. Vogrin B. Cepljenje in pediatrov ugovor vesti. 27. posvetovanje medicina, pravo in družba; sodobni izzivi in dileme. Konferenčni zbornik. Maribor: Univerzitetna založba univerze, 2018 23. Forster M. Ethical position of medical practitioners who refuse to treat unvaccinated children. J Med Ethics. 2019; 45 (8): 552-5.

24. Spencer JP, Trondsen Pawlowski RH, Thomas S. Vaccine adverse events: Separating myth from reality. Am Fam Physician. 2017; 95 (12): 786-94. 25. Opri R, Zanoni G, Caffarelli C, et al. True and false contraindications to vaccines. Allergol Immunopathol (Madr). 2018; 46 (1): 99-104.

26. Mintz K, Jardas E, Shah S, et al. Enrolling minors in covid-19 vaccine trials. Pediatrics. 2020

27. Haire $B$, Komesaroff $P$, Leontini $R$, et al. Raising rates of childhood vaccination: The trade-off between coercion and trust. J Bioeth Inq. 2018; 15 (2): 199-209.

28. Doherty M, Buchy P, Standaert B, et al. Vaccine impact: Benefits for human health. Vaccine. 2016; 34 (52): 6707-14

29. Schwartz JL, Caplan AL. Vaccination refusal: Ethics, individual rights, and the common good. Prim Care. 2011; 38 (4): 717-28, ix.

30. Browne $K$. The measles and free riders. Camb Q Healthc Ethics. 2016; 25 (3): 472-8.

31. Verweij MF, Houweling $\mathrm{H}$. What is the responsibility of national government with respect to vaccination? Vaccine. 2014; 32 (52): 7163-6.

32. Gostin LO. Public health law: Power, duty, restraint: University of California Press; 2008.

33. Navin MC, Attwell K. Vaccine mandates, value pluralism, and policy diversity. Bioethics. 2019; 33 (9): 1042-9.

34. Flanigan J. A defense of compulsory vaccination. HEC Forum. 2014; 26 (1): 5-25.

35. Giubilini A. Vaccination ethics. Br Med Bull. 2020.

36. Bechini A, Boccalini S, Ninci A, et al. Childhood vaccination coverage in Europe: Impact of different public health policies. Expert Rev Vaccines. 2019; 18 (7): 693-701.

37. Williamson L, Glaab H. Addressing vaccine hesitancy requires an ethically consistent health strategy. BMC Med Ethics. 2018; 19 (1): 84.

38. Cohen R, Gaudelus J, Leboucher B, et al. Impact of mandatory vaccination extension on infant vaccine coverages: Promising preliminary results. Med Mal Infect. 2019; 49 (1): 34-7.

39. Dosegljivo na: https://www.cdc.gov/vaccines/hcp/acip-recs/general-recs/contraindications. html.

40. Charron J, Gautier A, Jestin C. Influence of information sources on vaccine hesitancy and practices. Med Mal Infect. 2020; 50 (8): 727-33. 41. Tomljenovic M, Petrovic G, Antoljak N, et al. Vaccination attitudes, beliefs and behaviours among primary health care workers in northern croatia. Vaccine. 2021; 39 (4): 738-45.

42. Petravić L, Arh R, Gabrovec T, et al. Factors affecting attitudes towards covid-19 vaccination: An online survey in slovenia. Vaccines (Basel). 2021; 9 (3).
43. Haviari S, Bénet $T$, Saadatian-Elahi M, et al. Vaccination of healthcare workers: A review. Hum Vaccin Immunother. 2015; 11 (11): 2522-37. 44. Dosegljivo na: https://www.nijz.si/sites/www. nijz.si/files/uploaded/solarji_2019-2020.pdf.

45. Dosegljivo na: https://www.viva.si/ Infekcijske-bolezni/16582/S-cepljenjem-doza\%C5\%A1\%C4\%8Dite-proti-pnevmokoknim -oku\%C5\%BEbam.

46. Dosegljivo na: https://www.uradni-list.si/ glasilo-uradni-list-rs/vsebina? urlurid $=20202523$.

Meta Rus, dr. med.

Univerzitetni klinični center Ljubljana, Ljubljana, Slovenija

doc. dr. Urh Grošelj, dr. med. (kontaktna oseba / contact person) Klinični oddelek za endokrinologijo, diabetes in presnovne bolezni, Pediatrična klinika, Univerzitetni klinični center Ljubljana, Slovenija

Medicinska fakulteta, Univerza v Ljubljani, Ljubljana, Slovenija

Komisija Republike Slovenije za medicinsko etiko, Ministrstvo za zdravje, Ljubljana, Slovenija e-naslov: urh.groselj@kclj.si tel.: 015229235

prispelo / received: 11. 2. 2021 sprejeto / accepted: 21. 4. 2021

Rus M, Grošelj U. Etični vidiki cepljenja v otroštvu. Slov Pediatr 2021; 28(2): 78-85. https://doi.org/10.38031/slovpediatr-2021-2-02. 